DOI https://doi.org/10.18551/rjoas.2017-12.03

\title{
HOW ARE THE EFFECTS OF PROFITABILITY AND CAPITAL STRUCTURE ON STOCK RETURN WITH INFLATION AS A MODERATION VARIABLE?
}

\author{
Dewi Rahmatika*, Ramdhani Dadan \\ Master Program of Management, University of Esa Unggul, Jakarta, Indonesia \\ *E-mail: rahmatikadewi29@gmail.com
}

\begin{abstract}
This study aims to determine the effect of profitability and capital structure on stock return with inflation as a moderation variable; thus, it can reveal the strength or the weakness of the effect on stock return. Furthermore, financial statement data in this present research consist of 120 data from five manufacturing industry companies using method of analysis of General Linear Model. The result of this research is that profitability gives effect on increasing stock return of company and also the high capital structure increases company's stock return. Moreover, this study also reveals that inflation can moderate both profitability toward stock return and capital structure toward stock return. On the other hand, investor can see the three variables as a consideration for investment decision making.
\end{abstract}

\section{KEY WORDS}

Capital structure, inflation, profitability, stock return.

Investor uses company's financial information in shaping expectation of future profits from the capital invested in the company (Linck and Decourt, 2016). It is due to the reason that for an investor, the significant aspect they have to consider when evaluating an investment is how much potential that will be paid in the future compared to the risks that investor will get. Investor employs various ways to obtain the expected level of purchase, both by self-analysis and by realizing advices given by capital market analysts. Expectation regarding to financial performance of the company is essential in determining the company's stock price and it will give an impact on stock return level.

The financial performances in this study that affect stock return are profitability and capital structure. Profitability becomes one of the measurements of company's management effectiveness. Similarly, the company that uses funding sources to strengthen the capital structure cannot be considered as simple, but it is a strong implication towards what will happen in the next future.

The company's financial performance is not the main factor affecting stock return on a company. It is due to the fact that there are still many factors that affect stock return caused by other macro such as economy factor and market imperfection (Dehuan and Jin, 2008). Predicting return of a company needs information that can be clearly expressed in a financial statement. The published financial statements are considered having significance in assessing a company (Lev and Thiagarajan, 1993).

Therefore, the different effects of economy factor on stock return level support the idea that the stock market reacts rationally towards inflation and expected output growth (Sangkyun, 1997). Inflation is a tendency of occurrence in increasing the whole products' price. High inflation reduces the level of real income that investor gets from investment (Tandelilin, 2010). On contrary, if nation's inflation rate decreases; then it is a positive signal for investor to be in accordance with the decrease of purchasing power risk and the risk of real income decrease.

Inconsistent results provided in previous studies become the step to take alternative approach used in this present research. Inconsistent results open possibilities for moderating variables that may strengthen or weaken the effect of financial performance on stock return (Purnomo, 2013).

Hence, this present research is an attempt to examine the causal relationship between profitability and company capital structure in Indonesia with certain macroeconomic variables 
as moderation variables. It is with the research applied to manufacturing companies in Indonesia's stock market.

\section{THEORETICAL FRAMEWORK}

Dehuan and Jin (2008) explicate that the relationship between the company's stock return and its operating performance has been the research significant concern in recent years, however its research results are uncertain or inconsistent. Sangkyun's research (1997), in his study, found a positive relation on inflation toward stock return during the period of 1956 until 1995. Research data uses monthly data and quarterly financial data taken from the United States (U.S). The relative relation gives effect to inflation on stock return. This Inflation also uses monthly and quarterly data.

Moreover, Rahmani et al., (2006) examine about debt-to-equity ratio. However, the model is not significant for 2000 and 2001. In the single, D / E variables ratio is statistically insignificant. Besides, Dehuan and Jin's Research (2008) state that company's performance affects stock return on Shanghai stock exchange. It is in a study to investigate the relation between company performances regarding to Return on Assets. The variable return on assets (ROA) is significant in either one or two of the five-year examining period. The research conducted by Singh et al., (2011) reveals the relation between stock return and macroeconomic inflation variables. The results of the research conclude that the rate of inflation has a significant effect on stock return. Ouma and Muriu's research (2014) examines inflation towards stock return in Kenya during 2003-2013 periods using the Arbitrage Pricing Theory (APT) framework and Capital Asset Pricing Model (CAPM) model for monthly data. Ordinary Least Square (OLS) technique is applied to examine the validity of the model and the relative significance of different variables. Inflation affects stock return in Kenya's capital market. Inflation is found to be a significant return determinant in the NSE.

Hayat and Syed (2014) conduct a study aiming to know the impact of inflation on the stock market return of Karachi Stock Exchange and Pakistan's Bank website. The study uses the Augmented Dickey Fuller (AFU) root test to obtain the stationary data level and to find that the two variables are stationary at the first difference. The integration in this study is similar, so the study applies Johansen Co-integration test and concludes that there is a significant negative and long-term relation between the rate of inflation and the rate of the stock return. The increase in inflation gives negative impacts on stock prices that lead to the whole stock market. The research of Bora and Ag (2014) considers the effect of independent variables on stock return namely debt to equity ratio. The data used in the research are companies listed in the US and Turkish Markets as well as assessing their relation in terms of variables and panel data methods. The results of this study are relatively high and statistically significant; however it only occurs in the US' stock market and it does not occur in Turkey's stock market.

Return is the output gained from investment activity. It can be either in the form of the realized return that has occurred or the expected return that has not happened yet but it is expected to happen in the future. Stock Return is the profit or loss generated by investor from the stock market. Stock Return is highly important because it is the main purpose of investment in common stock. In the secondary market, an investor can get a stock market return by buying stock at a lower price and selling it at a higher price level (Ibrahim and Bala, 2017).

Profitability ratio is the ratio to examine the company's capability to gain profit. It is the definition of profitability proposed by Kasmir (2011). According to Brigham (2006), it is mentioned that profitability is the final output of the company's management performance, both in decision-making and policy run by associated management regarding to the use of funds for the realization of the company and the company's funding sources; so it is made one in a report namely balance sheet.

Capital structure is the ratio between debt and equity; capital structure is an essential problem in making decision about purchase (Yasa, 2013). According to Bhandari (1988), 
theoretically when the debt total of a company replaces its equity total, the shareholder will demand a high rate of return on his or her share because of the high risk of bankruptcy.

Inflation is a tendency of prices which generally increase or decrease continuously (Mankiw, 2003). The increase is a widespread increase (various sectors). Inflation is one of the nation's economy measurements. It is also a condition that arises because there is no balance between demand for goods and its supply. High inflation leads to a decrease of the company's profits which makes equity effects become less competitive (Hayat and Syed, 2014). From the previous studies, the hypothesis in this study is shown in Figure 1.

$\mathrm{H} 1$ : The higher profitability, the higher stock return.

$\mathrm{H} 2$ : The greater capital structure, the higher stock return. In this present study, inflation is used as a moderation variable.

$\mathrm{H} 3 \mathrm{a}$ : Especially for high inflation period, companies having high ROA will gain larger stock returns than companies having few ROA.

H3b: Especially for the company's ROA condition which is less, companies experiencing low inflation has a stock return more than companies experiencing high inflation.

H3c: Especially for low inflation period, companies having high ROA will gain higher stock returns than companies having few ROA.

H4a: Especially for high inflation period, companies having many DERs will gain larger stock returns than companies having few DER.

$\mathrm{H} 4 \mathrm{~b}$ : Especially for the condition where the companies having few DER, companies experiencing low inflation has more stock return than companies experiencing high inflation.

H4c: Especially for low inflation period, companies having many DERs will gain more share returns than companies having few DER.

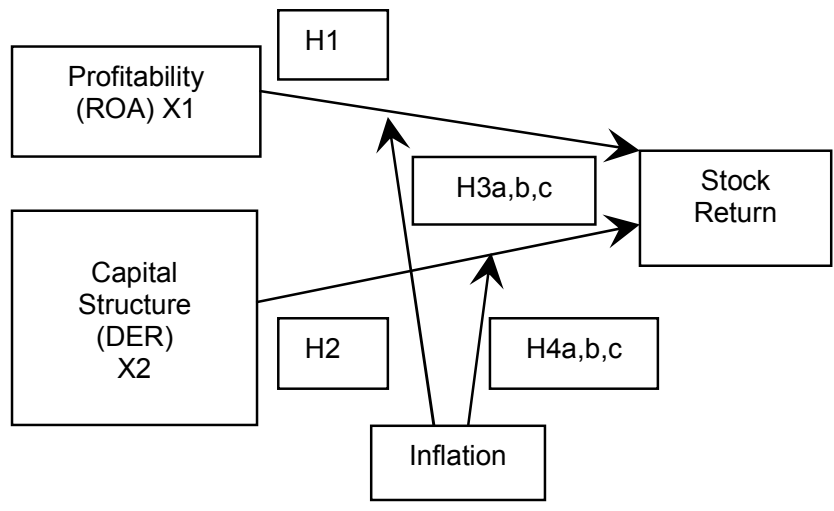

Figure 1 - Method of Research Hypothesis

(Source: Previous Studies that have been re-processed, 2017)

\section{METHODS OF RESEARCH}

The data employed is financial statement data of manufacturing industry companies listed on Indonesia Stock Exchange (IDX) starting in 2011-2016. To know whether there is a relation between stock return and financial ratio, this present study utilizes non-hierarchical statistical model with data processed using General Linear Model (GLM) statistical software (Agung, 2006). In data analysis, basically it has an aim to study the difference of in-average response variables or indicators of certain problems between individual groups including in testing hypotheses about the differences in the population which is under review. The average cell function has a reciprocal relation with the cell's average table. It can be seen on the table that presents the mean (average) of the dependent variable or indicator of a particular problem by a factor or multifactor (Agung, 2005). The samples in this research are five manufacturing industry companies in which each company has quarterly financial statement data for six years. Therefore, the sample data used is of 120 data. 
It is about the company's capability to make profit. Profitability in this study will be projected towards the return on Assets (ROA) (Sugiyono, 2009). The long-term permanent funding of the company is represented by debt, equity, preferred stock, and common stock. This research is the capital structure research specifically Debt to Equity Ratio (DER) (Kasmir, 2011). Inflation or the price increase caused by the scarcity of production that affects the increase in production costs (Insukindro, 1993). Return is the level of profit obtained by investor on an investment that he or she performs (Jogiyanto, 2013). Data analysis technique used in the present research is descriptive-comparative statistic which is a technique of data analysis utilized by describing data which have been accumulated as the presence of independent variable value, either one variable or more; then make a comparison or connect between one variable and the other variable proceeded by making conclusion applied to the public or generalization (Sugiyono, 2009). The classical assumption test is a test used to determine whether the multiple regression model employed in this study meets the classical assumption or not (Ghozali, 2016).

\section{RESULT OF STUDY}

The analysis in this study, as it can be seen in Table 1, where the test of hypothesis 1 using the statistical $F$ test on the path 'ROA' where $F 0=33,951$ (Sig 0,000), with the degree of freedom $1 / 116$. It reveals the rejection of $\mathrm{HO}$, so it can be concluded that the data supports the proposed hypothesis. It shows that stock return is affected by ROA. The company's high profit will increase the company's stock return in manufacturing industry companies in Indonesia.

Table 1 - Test of Between-Subject Effects

Dependent Variable: Stock Return

\begin{tabular}{|c|c|c|c|}
\hline Source & df & $\mathrm{F}$ & Sig. \\
\hline Corrected Model & 3 & 15,920 &, 000 \\
\hline Intercept & 1 & ,981 & ,324 \\
\hline ROACODE & 1 & 33,951 &, 000 \\
\hline INFLASICODE & 1 & ,205 &, 652 \\
\hline ROACODE * INFLASICODE & 1 & 1,851 &, 176 \\
\hline Error & 116 & & \\
\hline Total & 120 & & \\
\hline Corrected Total & 119 & & \\
\hline
\end{tabular}

Source: Data that have been processed by using SPSS statistical tool.

Table 2 - Parameter Estimate Design $A\left(A^{*} B\right)$

\begin{tabular}{|c|c|c|c|c|c|}
\hline Parameter Intercept & \multirow{2}{*}{ Note } & $\mathrm{B}$ & $\beta$ & $\mathrm{t}$ & Sig. \\
\cline { 3 - 6 } & &,- 481 & $\beta 0$ & $-5,868$ &, 000 \\
\hline$[\mathrm{ROACODE}=1,00]$ & $\mathrm{ROA}=1$ &, 895 & $\beta 1$ & 5,082 &, 000 \\
\hline$[\mathrm{ROACODE}=2,00]$ & $\mathrm{ROA}=2$ & $0^{\mathrm{a}}$ & &. &. \\
\hline $\begin{array}{c}{[\mathrm{INFLASI}} \\
\text { CODE=1,00] }\end{array}$ & $\mathrm{INF}=1$ &, 113 & $\beta 2$ &, 642 &, 522 \\
\hline $\begin{array}{c}{[\mathrm{INFLASI}} \\
\text { CODE=2,00] }\end{array}$ & $\mathrm{INF}=2$ & $0^{\mathrm{a}}$ & - & - & - \\
\hline $\begin{array}{c}\text { CODE=1,00] } \\
\text { CODLASI }\end{array}$ & &,- 339 & $\beta 3$ & $-1,361$ &, 176 \\
\hline
\end{tabular}

Source: Data that have been processed by using SPSS statistical tool.

Table 2 shows the testing of hypothesis 3, the values that will be tested are in the "inflation" group, by comparing the many ROAs and the few ROAs with the efficient coefficients. This test is conducted to see the difference of gap in stock return, mean deviation $(Y)$ formed by the many ROA $(R O A=1)$ profitability $(R O A)$, and the few ROA (ROA $=2$ ) both in inflation group (INF), low inflation (INF = 1) and high inflation (INF = 2) after considering the similar linear ROA $(X)$ on stock return $(Y)$ in all cells. The results of the 
analysis support hypothesis $\mathrm{H} 3 \mathrm{a}$ : Especially for high inflation periods, companies having high ROA will gain larger stock returns than companies having few ROA. ( $\beta 1)$, with sig. value of $0,000(<0,05)$. In the test results, it is found that the results of the analysis do not support the hypothesis of H3b: Especially for the company's ROA condition which is less, companies experiencing low inflation has a stock return more than companies experiencing high inflation $(\beta 2)$, with sig. value of $0,522(>0,05)$.

In the result of $\mathrm{H} 3 \mathrm{c}$ hypothesis: Especially for low inflation period, companies having high ROA will gain higher stock returns than companies having few ROA ( $\beta 3$ ) with sig. value of $0,176(>0,05)$. The analysis in this study, as can be seen in Table 3 , where the test of hypothesis 1 using the statistical $F$ test on the path 'DER' where F0 = 27,956 (Sig 0,000), with the degree of freedom 1/116. It reveals the rejection of $\mathrm{H} 0$, so it can be concluded that the data supports the proposed hypothesis. It also shows that stock return is affected by DER. A high capital structure for company's expansion costs will increase the company's stock return on manufacturing companies in Indonesia with a debt-to-equity level limit.

Table 3 - Test of Between-Subject Effects

\begin{tabular}{|c|c|c|c|}
\hline Source & $\mathrm{df}$ & $\mathrm{F}$ & Sig. \\
\hline Corrected Model & 3 & 13,623 &, 000 \\
\hline Intercept & 1 & 2,057 & , 154 \\
\hline DERCODE & 1 & 27,956 &, 000 \\
\hline INFLASICODE & 1 & ,974 & ,326 \\
\hline DERCODE * INFLASICODE & 1 & 1,461 &, 229 \\
\hline Error & 116 & & \\
\hline Total & 120 & & \\
\hline Corrected Total & 119 & & \\
\hline
\end{tabular}

Source: Data that have been processed by using SPSS statistical tool.

This test is done to see the difference gap in stock return, mean deviation $(Y)$ formed by many DER (DER = 1) capital structure (DER), and few DER (DER = 2) both in inflation group (INF), low inflation (INF = 1) and also high inflation (INF = 2) after considering the similar linear DER $(X)$ on stock return $(Y)$ in all cells. The results can be seen in Table 4 for testing hypothesis 4 , the values that will be tested are in the "inflation" group by comparing the many DER and the few DER with efficient coefficients.

Table 4 - Parameter Estimate Design A $\left(A^{*} B\right)$

Dependent Variable: Stock Return

\begin{tabular}{|c|c|c|c|c|}
\hline Parameter Intercept & $\mathrm{B}$ & $\beta$ & $\mathrm{t}$ & Sig. \\
\hline &, 233 & $\beta 0$ & 1,722 &, 088 \\
\hline$[\mathrm{DERCODE}=1,00]$ &,- 743 & $\beta 1$ & $-4,593$ &, 000 \\
\hline$[\mathrm{DERCODE}=2,00]$ & $0^{\mathrm{a}}$ & - & - &.- \\
\hline$[\mathrm{INFLASICODE}=1,00]$ &,- 025 & $\beta 2$ &,- 157 &, 876 \\
\hline$[\mathrm{INFLASICODE}=2,00]$ & $0^{\mathrm{a}}$ & & & \\
\hline$[\mathrm{DERCODE}=1,00]^{*}[\mathrm{INFLASICODE=1,00]}$ &, 277 & $\beta 3$ & 1,209 &, 229 \\
\hline
\end{tabular}

Source: Data that have been processed by using SPSS statistical tool.

The results of the analysis support hypothesis H4a: Especially for high inflation period, companies having many DERs will gain larger stock returns than companies having few DER $(\beta 1)$, with sig. value of $0,000(<0,05)$. In the result of hypothesis $4 b$ testing, it is found that the results of analysis do not support hypothesis $4 \mathrm{~b}$ : Especially for the condition where the companies having little DER, companies experiencing low inflation has more stock return than companies experiencing high inflation $(\beta 2)$, with sig. value of $0,876(>0,05)$. On the other hand, the result of hypothesis $4 \mathrm{c}$ testing, it is found that the results of analysis do not support H4c: Especially for low inflation period, companies having many DERs will gain more share returns than companies having little DER $(\beta 3)$ with sig value of $0,229(<0,05)$. 


\section{DISCUSSION OF RESULTS}

In the results of testing on hypothesis 1 , it is found that the analysis results support hypothesis 1 that the higher profitability, the higher stock return. The results of this study are in line with the results of previous research conducted by Dehuan and Jin (2008) stating that there is a significant relation between ROA and stock return. It shows that ROA that becoming larger describes the company's better performance and investor will be interested in investing capital in the company so that if ROA increases, it will increase the stock price and will affect the increase of stock return as well.

Besides, in the results of testing on hypothesis 2 , it is found that the results support $\mathrm{H} 2$ hypothesis that the greater capital structure, the higher stock return. The results of this study are in accordance with the results of previous research conducted by Bora and Ag (2014) explicating that there is a significant relation between DER and stock return. An increase in a company's DER increases the risk of a joint equity. With a higher level of risk, the expected rate of return is also higher.

Furthermore, in the results of testing on hypothesis $3 a$, it is found that the analysis results support hypothesis $3 a$ which is especially for high inflation periods, companies having high ROA will gain larger stock returns than companies having few ROA. The results of this study support the results of previous research conducted by Sangkyun, (1997); Singh et al., (2011); Ouma and Muriu (2014); Hayat and Syed (2014) emphasizing that inflation has a significant effect on stock return.

Next, in the result of testing on hypothesis $3 b$, it is found that the result of analysis does not support hypothesis $3 \mathrm{~b}$ that especially for the company's ROA condition which is less, companies experiencing low inflation has a stock return more than companies experiencing high inflation gives result that inflation does not have significant effect on stock return.

Moreover, in the results of testing on hypothesis 3c, it is found that the results of the analysis do not support the hypothesis $3 c$ stating that especially for low inflation period, companies having high ROA will gain higher stock returns than companies having few ROA gives results that ROA is not significant towards stock return. Besides, in the results of on hypothesis 4 a testing, it is found that the analysis results support the hypothesis $4 a$ which is especially for high inflation period, companies having many DERs will gain larger stock returns than companies having few DER. In other words, if the DER is below 1.00 , it indicates that the company's stock is larger than the loan owned by the company; therefore even if the DER is high, but it is still within the limit of the highest figure of 1.

Next, in the testing results in hypothesis $4 \mathrm{~b}$, it is found that the analysis do not support the hypothesis $4 \mathrm{~b}$ stating that especially for the condition where the companies having few DER, companies experiencing low inflation has more stock return than companies experiencing high inflation. Ultimately, the testing results in hypothesis $4 \mathrm{c}$ reveal that the analysis do not support the hypothesis 4c which is especially for low inflation period, companies having many DERs will gain more share returns than companies having few DER. The results of this study support the results of previous research conducted by Rahmani et al., (2006) proving the result that DER does not give significant effect on stock return. The many DER does not attract the interest of the investor because the investor considers that company having many debts, especially from debt loans (creditor), goods will become the interest burden of the company.

\section{CONCLUSION AND SUGGESTIONS}

The first result of this study is that the profitability (ROA) affects stock return. It is shown that the higher profitability (ROA) of manufacturing companies, the higher the stock return (the first hypothesis is supported). The high profitability (ROA) becomes the interest of investor to invest in manufacturing companies because it will make high stock return.

The second conclusion from the results of this study is that the higher the capital structure (DER), the more increasing stock return (the second hypothesis is supported). Based on the results of the present research, the large DER with the DER value which still 
has normal limit will be very attractive for investor to invest in the manufacturing companies. Because investor can see that the high DER is obtained to re-manage or used for company's expansion decisions. If the high DER is caused by the amount of current debt is greater than long-term debt, it can still be accepted because the amount of current debt is often caused by short-term operating debt.

With the result of research moderated by variable inflation research, it can be taken a result that inflation can moderate the relation between profitability on stock return and capital structure on stock return.

Limitation in this study can be used as a basis for upcoming researches which are more focused. The industry used in this research is only in the Manufacturing Company Listed in Indonesia Stock Exchange period in 2011 until 2016; moderation variables used in this study are just the inflation variables.

By considering other industry sectors, other industry companies' data can be used in order to know the results from different industry sectors. In the further moderation research, macroeconomic factors of the company consist of some others such as interest rates and exchange rates; and it can be used as a reference for further research. Investor, in this case, is related to invest in stock of manufacturing companies; variable profitability, capital structure, and macroeconomic inflation will be a good consideration in decision making.

\section{REFERENCES}

1. Agung, I.G.N. (2005). Statistika Penerapan Model Rerata-sel dan Model Alternatif dengan SPSS. Jakarta:

2. Agung, I.G.N. (2006). Statistika Penerapan Model Rerata-sel Multivariate dan Model Ekonometri dengan SPSS. Jakarta: Yayasan SAD SATRIA BHAKTI.

3. Bhandari, L. C. (1988). Debt-Equity Ratio and Expected Common Stock Returns: Empirical Evidence. Journal of Finance, 43, 507-528.

4. Bora, S. Y., \& Ag, Y. (2014). Explaining the cross section of stock returns: A comparative study of the United States and Turkey. Procedia-Social and Behavioral Sciences, 109, 327-332.

5. Brigham, E.F., \& Joel F. H. (2006). Fundamentals of Financial Management, 10th Edition. South-Western:

6. Dehuan, J., dan Jin, Z. (2008). Firm Performance and Stock Returns : An Empirical Study of The Top Performing Stocks Listed on Shanghai Stock Exchange. Academy of Accounting and Financial Studies Journal, 12(1), 79-85.

7. Ghozali, I. (2016). Aplikasi Analisis Multivariete dengan Program IBM, Edisi ke-8. Semarang: Badan Penerbit Universitas Diponegoro.

8. Hayat, Y. \& Syed, N.A. (2014). Impact of Inflation on Stock Exchange Market Returns, European Academic Research, Vol. I, Issue 11.

9. Ibrahim, I., \& Bala, H. (2017). Firms Specific Characteristic and Stock Market Returns (Evidence From Listed Food and Beverage Firms in Nigeria). International Journal of Information, Business and Management, Vol. 9, No.1.

10. Insukindro. (1993). Ekonomi Uang, Bank, Teori dan Pengalaman di Indonesia, Yogyakarta: BPFE.

11. Jogiyanto, H.M. (2014). Teori Portofolio dan Analisa Investasi, Edisi 9. Yogyakarta: BPFE.

12. Lev, B. \& Thiagarajan, R. (1993). Fundamental Information Analysis, Theory, Application and Interpretation. Sixth Edition, Vol 13 No.2 (autumn), pp 190-215.

13. Linck, L, \& Decourt, R.F. (2016). Stock Returns, Macroeconomic Variables and Expectations. Evidence from Brazil. ISSN 1657-6276.

14. Mankiw, N. G., (2003). Teori Makro Ekonomi. Edisi kelima. Alih Bahasa Imam Nurmawan. Jakarta: Erlangga.

15. Ouma, W.N. \& Muriu, P. (2014). The Impact of Macroeconomic Variables on Stock Market Return in Kenya. International Journal of Business and Commerce, Vol. 3, No.11: July 2014[01-31] (ISSN: 2225-2436). 
16. Purnomo, M.Y.P. (2013). Pengaruh Kinerja Keuangan terhadap Return Saham dengan Inflasi sebagai Variabel Moderasi pada Perusahaan Manufaktur yang Terdaftar di Bursa Efek Indonesia. Undergraduate Thesis. STIE Perbanas Surabaya.

17. Rahmani, A., Sauber, S., \& Elnaz, T. (2006). Accounting Variables, Market Variables and Stock Return in Emerging Markets : Case of Iran.

18. Sangkyun, P. (1997). Rationality of Negative Stock Price Responses to Strong Economics Activity. Journal Financial Analyst.

19. Singh, T, Mehta, S \& Varsha, M. S. 2011. Macroeconomic Factors and Stock Returns: Evidence from Taiwan. Journal of Economics and International Finance Vol. 2(4), pp.217227. ISSN 2006-9812.

20. Sugiyono. (2009). Metode Penelitian Pendidikan Pendekatan Kuantitatif, Kualitatif dan R\&D. Bandung: Alfabeta.

21. Tandelilin, E. (2010). Portofolio dan Investasi. Yogyakarta: Kanisius.

22. Yasa, I.G.A.S. (2013). Teori Struktur Modal (Online). 